\title{
A Bruce Chatwin bibliography
}

It may seem obvious to the point of banality to observe that Bruce Chatwin was a voracious reader, yet there have been few significant writers of the last century whose breadth and diversity of reference could match Chatwin's. He was referred to by John Updike as the 'demon researcher' (I28) for good reason; Elizabeth Chatwin recalls once finding 50 books by his bedside whilst tidying, all of which were being read simultaneously: ' $[\mathrm{H}] \mathrm{e}$ could never go past a book store', she comments. 'It was just a total fascination' (20I0). His wide-ranging reading habits bred a seemingly inexhaustible knowledge base; Salman Rushdie has referred to him as 'probably the most knowledgable person amongst my contemporaries that I ever met' (Footsteps). His references sometimes eluded his friends, however; Redmond O'Hanlon recalled an early morning conversation with Bruce in which Bunin ${ }^{1}$ was mentioned; after Chatwin had rung off, O'Hanlon began 'wondering who or what Bunin was: with Bruce you could never be sure. The new Stravinksy from Albania? The nickname of the last slave in Central Mali? A lighthouse-keeper from Patagonia? Scroll 238B from a cave in the Negev? Or just the émigré King of Tomsk who'd dropped in for tea?' (Іо3).

Bruce's library remains more or less intact at his home in Oxfordshire, though some significant volumes were given away to friends. It is a sizable collection; taking up two long walls of floor-to-ceiling shelving in his study, as well as various bookcases dotted around the house. The most common writers are European, particularly Russian: Turgenev, Pushkin, Tolstoy, Dostoevsky, Bunin, Gogol and, of course, Osip Mandelstam. The French are also well represented, often in the original language (Chatwin had intended to learn Russian in the period of remission ultimately given over to the writing of $U t z$ ); the works of Balzac, Proust, Maupassant (whose short stories are particularly well thumbed), Racine and Flaubert are all in evidence. There is relatively little modern fiction on the shelves (though Borges and Italo Calvino are both strong presences), and very little from the United Kingdom - D.H. Lawrence being the obvious exception. There is also a substantial amount of poetry; Ezra Pound's Cantos appear in various editions, as do the poems of the Alexandrian poet C.P. Cavafy. Also 
evident on the shelves are T.S. Eliot and, a perpetual favourite, Matsuo Basho.

What follows, however, is not intended as a definitive record of Chatwin's reading - which would constitute a monumental task. Nor is it intended as a record of his favourite works; Nicholas Shakespeare's 'A Chatwin Reading List' (2000: 579-80) in his biography is an excellent starting point for those interested in his preferences. Rather, this bibliography is intended to provide a guide to some of the books which directly influenced Chatwin's literary output, either on the level of style or subject. It is, by its nature, selective, though the section relating to The Nomadic Alternative is intended as more extensive, given that work's lack of public availability, and its influence upon Chatwin's later output.

\section{The Nomadic Alternative}

An Account of the Kingdom of Caubul, Mountstuart Elphinstone

The Anarchists, James Joll

The Anatomy of Melancholy, Robert Burton

Anima Poetae: From the unpublished notebooks of Samuel Taylor Coleridge, Samuel

Taylor Coleridge

Aranda Traditions, Theodor Strehlow

The Art of War, Sun Tzu

Beowulf

The Buddha's Philosophy, George Francis Allen

Buddhist Monks and Monasteries of India: Their History and Their Contribution to Indian Culture, Sukumar Dutt

Bushmen and other non-Bantu peoples of Angola, António de Almeida

Che Guevara: A Biography, Daniel James

Clouds, Aristophanes

Collected Poems, C.P. Cavafy

The Dhammapada

A Discourse on Inequality, Jean-Jacques Rousseau

The Divine Comedy, Dante Alighieri

Essay on the Inequality of Human Races, Joseph Arthur Comte de Gobineau

Ethnological Studies among the north-west-central Queensland aborigines, Walter Edmund

Roth

The Evolution of Man and Society, C.D. Darlington

The Flowers of Evil, Charles Baudelaire

Germania, Cornelius Tacitus

The Ghost-Dance Religion and the Sioux Outbreak of 1890, James Mooney

The Ghost in the Machine, Arthur Koestler

The Ghost of Abel: A Revelation in the Visions of Jehovah, William Blake

Gilgamesh

Inner Asian Frontiers of China, Owen Lattimore 
In Search of Lost Time, Marcel Proust

Intimate Journals, Charles Baudelaire

Ishi in Two Worlds: A Biography of the Last Wild Indian in North America, Theodora Kroeber

Journals of Two Expeditions of Discovery in North-West and Western Australia during the years 1837, 38, and 39, Sir George Grey

Journal Up the Straits, October 11, 1856-May 5, 1857, Herman Melville

Ladder of Paradise, Saint John Climacus

Leaves of Grass, Walt Whitman

Leviathan, Thomas Hobbes

Man the Hunter, ed. Richard B. Lee and Irven Devore

Moses: The Revelation and the Covenant, Martin Buber

Muqaddimah, Ibn Khaldun

Mutual Aid: A Factor of Evolution, Petr Kropotkin

Pensées, Blaise Pascal

Personal Narrative of a Year's Journey Through Central and Eastern Arabia (1862-63), William Palgrave

The Phenomenon of Man, Pierre Teilhard de Chardin

The Pilgrim's Progress, John Bunyan

The Poems of St John of the Cross, St John of the Cross

Poetic Essay on Living in the Mountains, Hsieh Ling-yün

Politics, Aristotle

Primitivism and Related Ideas in Antiquity, Arthur O. Lovejoy and George Boas

The Pursuit Of The Millennium: Revolutionary Millenarians and Mystical Anarchists of the Middle Ages, Norman Cohn

The Road, Jack London

Le Roman de la Rose, Guillaume de Lorris and Jean de Meun

The Savage Mind, Claude Lévi-Strauss

Seven Pillars of Wisdom: A Triumph, T.E. Lawrence

The Spiritual Meadow, John Moschos

Statism and Anarchy, Mikhail Bakunin

Tao Te Ching, Lao Tzu

$A$ Thousand Years of the Tartars, Edward Harper Parker

Travels in Arabia Deserta, Charles Montagu Doughty

Urne Burial, Thomas Browne

Walden, Henry David Thoreau

The Wandering Scholars of the Middle Ages, Helen Waddell

Wayward Servants: The Two Worlds of the African Pygmies, Colin Turnbull

Wonders of the Invisible World, Cotton Mather

Works and Days, Hesiod

The Wretched of the Earth, Frantz Fanon 


\section{In Patagonia}

Idle Days in Patagonia, W.H. Hudson

In Our Time, Ernest Hemingway

Journey to Armenia, Osip Mandelstam

Magellan's Voyage: A Narrative Account of the First Circumnavigation, Antonio

Pigafetta

The Narrative of Arthur Gordon Pym of Nantucket, Edgar Allen Poe

Uttermost Part of the Earth, E. Lucas Bridges

The Voyage of the Beagle, Charles Darwin

The Wilds of Patagonia: A Narrative of the Swedish Expedition to Patagonia, Tierra del

Fuego and the Falkland Islands in 1907-1909, Carl Skottsberg

\section{The Viceroy of Ouidah}

Almayer's Folly, Joseph Conrad

Bahia and the West African Trade 1549-1851, Pierre Verger

Bajazet, Jean Racine

Dahomey as It Is: Being a Narrative of Eight Months' Residence in That Country, J.A.

Skertchly

Eugénie Grandet, Honoré de Balzac

A Mission to Gelele, King of Dahome, Richard Burton

Salambo, Gustave Flaubert

\section{On the Black Hill}

Collected Poems, Dylan Thomas

The Double: A St Petersburg Poem, Fyodor Dostoyevsky

The Fox in the Attic, Richard Hughes

Gone to Earth, Mary Webb

Kilvert's Diary, 1870-1879: Selections from the Diary of the Rev. Francis Kilvert, Francis

Kilvert

Madame Bovary, Gustave Flaubert

The Nose, Nikolai Gogol

Poems, Dafydd ap Gwilym

A Shropshire Lad, A.E. Housman

The Strange Case of Dr Jekyll and Mr Hyde, Robert Louis Stevenson

Studies in Early Celtic Nature Poetry, Kenneth Jackson

Tess of the d'Urbervilles, Thomas Hardy

Welsh Rural Life in Photographs, Elfyn Scourfield 


\section{The Songlines}

Being and Time, Martin Heidegger

Dialogues, Plato

The Hunters or the Hunted?, Charles Kimberlin Brain

Jacques the Fatalist, Denis Diderot

Kangaroo, D.H. Lawrence

Metamorphoses, Ovid

On Aggression, Konrad Lorenz

Songs of Central Australia, Theodor Strehlow

\section{Utz}

Fictions, Jorge Luis Borges

The Golem, Gustav Meyrink

Illuminations, Walter Benjamin

The Magic Mountain, Thomas Mann

Metamorphosis, Franz Kafka

Prague Tales, Jan Neruda

NOTE

I Ivan Bunin, I870-I953, was a Nobel Prize-winning Russian writer of poems, short stories and novellas. His story collection Dark Avenues was a particular favourite of Chatwin's. 